\title{
Anti-dumping: A Growing Problem in International Trade
}

\author{
Thomas J. Prusa \\ Rutgers University
}

\section{INTRODUCTION}

\begin{abstract}
$\mathcal{T}$ OR most of its 100 years of existence, anti-dumping (AD) was not nearly the problem that it is today. In fact, for most of its existence it is fair to say that $\mathrm{AD}$ could hardly have been called a problem for the international trading community. Over its first 70 years, $A D$ was neither widely adopted nor were AD duties widely imposed by the handful of countries who were AD users. Over the last 30 years, however, $\mathrm{AD}$ has emerged as the leading obstacle to the free and fair trading system established under the GATT/WTO.
\end{abstract}

$\mathrm{AD}$ a problem? For some this statement must seem odd. Isn't $\mathrm{AD}$ the policy that corrects a dumping problem? The short answer, is 'no'. As it turns out, the link between dumping and anti-dumping duties is tenuous. A century ago one could plausibly argue that predatory dumping was more of a problem than antidumping. The same cannot be said today. WTO-sanctioned use of AD surely causes more injury than any reasonable person's notion of economically harmful dumping. Today AD is a bigger problem for international trade than economically meaningful dumping (Miranda, Torres and Ruiz, 1998; Shin, 1998; Prusa, 2000; Zanardi, 2004; and Blonigen, 2003).

To borrow an analogy, I am arguing that the medication (anti-dumping) is more harmful than the disease it was originally intended to treat (economically harmful dumping). One of the goals of this paper is to explain how this can be. There are two primary points to my argument. First, there is the proliferation problem. To continue the analogy, the amount of medication being administered exceeds what any reasonable doctor would prescribe to treat the disease. Second and perhaps more disconcerting it turns out that modern $\mathrm{AD}$ law has nothing to do with economically harmful practices; rather, $\mathrm{AD}$ is just a cleverly designed

The author wishes to thank the WTO Rules Division and Jorge Miranda in particular and for making the WTO AD Measures Database available. As always, all mistakes and errors are the author's responsibility. 
form of protectionism. In other words, not only is too much medication being administered but the medication has nothing to do with the disease it is supposedly intended to be addressing.

Section 2 discusses the proliferation issue. I will show that AD is used more frequently, by more countries, and against more products than ever in its history. $\mathrm{AD}$ is no longer being used solely by high-income developed countries. It is increasingly being used by middle- and even lower-income countries. At least as worrisome, these new users have chosen to use AD very intensively. Per dollar of imports the new users have filed $\mathrm{AD}$ cases up to 15-20 times more frequently than the traditional $\mathrm{AD}$ users such as the United States and European Union (EU).

Section 3 discusses the rationales for modern AD. I will explain that, despite the rhetoric often bandied about, AD statutes no longer have anything to do with predation or even economically harmful dumping. ${ }^{1}$ The predatory intent provision included in the earliest versions of the law was expunged more than 75 years ago. Ironically, one of the most basic lessons that one must learn is that modern $\mathrm{AD}$ has nothing to do with what microeconomics says is harmful pricing behaviour. $\mathrm{AD}$ is not about restraining an economically harmful dumping. It is just a clever form of protectionism.

I conclude with some thoughts on whether these trends should be viewed hopefully or bleakly.

\section{RECENT TRENDS IN AD USAGE}

In this section I will review and discuss trends in AD use. Let me mention at the outset that quality of data regarding AD activity varies considerably across time and countries. One serious shortcoming is that there is no systematic accounting of worldwide AD activity before 1980. From what I can ascertain, the United States is the only country for which comprehensive activity data are available prior to 1980. For AD's first 75 years, all one knows is the year that each country enacted its first AD statute. While clearly an imperfect measure of $\mathrm{AD}$ activity, it does offer a perspective on the breadth and spread of AD.

Considerably better data are available since 1980. Since 1980 the GATT/WTO has required member countries to make semi-annual reports of their AD activity. These reporting data are pretty complete in that most AD disputes are reported. There are a couple of caveats. First, the reports contain only basic information on dispute outcomes and only a broad description of the product involved (e.g., no

${ }^{1}$ When one considers that the GATT AD statute never has contained such a provision requiring proof of predatory dumping, it is surprising that $\mathrm{AD}$ supporters continue to use predation to justify AD's existence. 
information on tariff lines). Second, it appears that the official country submissions to the GATT/WTO occasionally conflict with internal country records. For instance, for the United States, the country with which I am most familiar and which has probably the best public reporting, there are more than 20 cases which the United States initiated but did not report to the GATT. All of these cases were quickly settled or withdrawn and no official preliminary determinations were ever made. Nevertheless, there are reasons to believe that even short-lived cases can impact the market, so one would like all such cases to be reported (Anderson, 1992; and Prusa, 1992). Given that the GATT/WTO accepts these reports as submitted, it is reasonable to expect that other countries' submissions also contain mistakes. Third, the GATT/WTO rules are unclear whether AD actions against non-WTO members must be reported. It appears that most countries report cases against major targets such as PR China and Russia; it is not clear, on the other hand, that all disputes involving smaller non-WTO countries are reported. Fourth, AD actions by non-WTO countries are not reported. ${ }^{2}$

Recognising these limitations, I nevertheless use the WTO reports 'as is' with one exception. Under EU law, AD cases are filed on behalf of all EU countries. AD cases are not filed by Germany or France or any individual country, but by the EU. AD duties are imposed on the subject product regardless of what port it enters the EU. In contrast, AD cases can be filed against the entire EU or against individual countries. To keep the accounting consistent, when a country simultaneously files $\mathrm{AD}$ cases involving the same product against multiple EU countries, I convert the multiple filings into a single $\mathrm{AD}$ action against the EU. For example, an AD investigation against France, Germany and Spain would be counted as a single case against the EU. As a result, according to my accounting, $\mathrm{AD}$ cases are filed by and against the EU, not against any individual member country. This reduces the total number of cases by about 300 over the 1980-2001 period.

\section{a. $A D-A$ Worldwide Phenomenon}

Figure 1 depicts the decade-by-decade growth in the number of countries with an AD statute. Notice that, until the mid-1950s, AD was a trade policy that only eight countries - Canada, Australia, South Africa, the United States, Japan, France, New Zealand and the United Kingdom - even had. While a careful accounting of the use of $\mathrm{AD}$ by these countries during its first 75 years is not available, the fact that only eight countries even had an AD statute suggests that the scope for $\mathrm{AD}$ to be a serious nuisance was limited.

Because so few countries actively used AD it is not terribly surprising that trade negotiators perceived little risk in incorporating $\mathrm{AD}$ provisions into the

\footnotetext{
${ }^{2}$ Zanardi (2004) reports that this omission probably leads to under-reporting worldwide activity by 100-200 actions over the 1980-2001 period.
} 
FIGURE 1

Spread of AD, by Decade, 1904-09 to 1990-Present

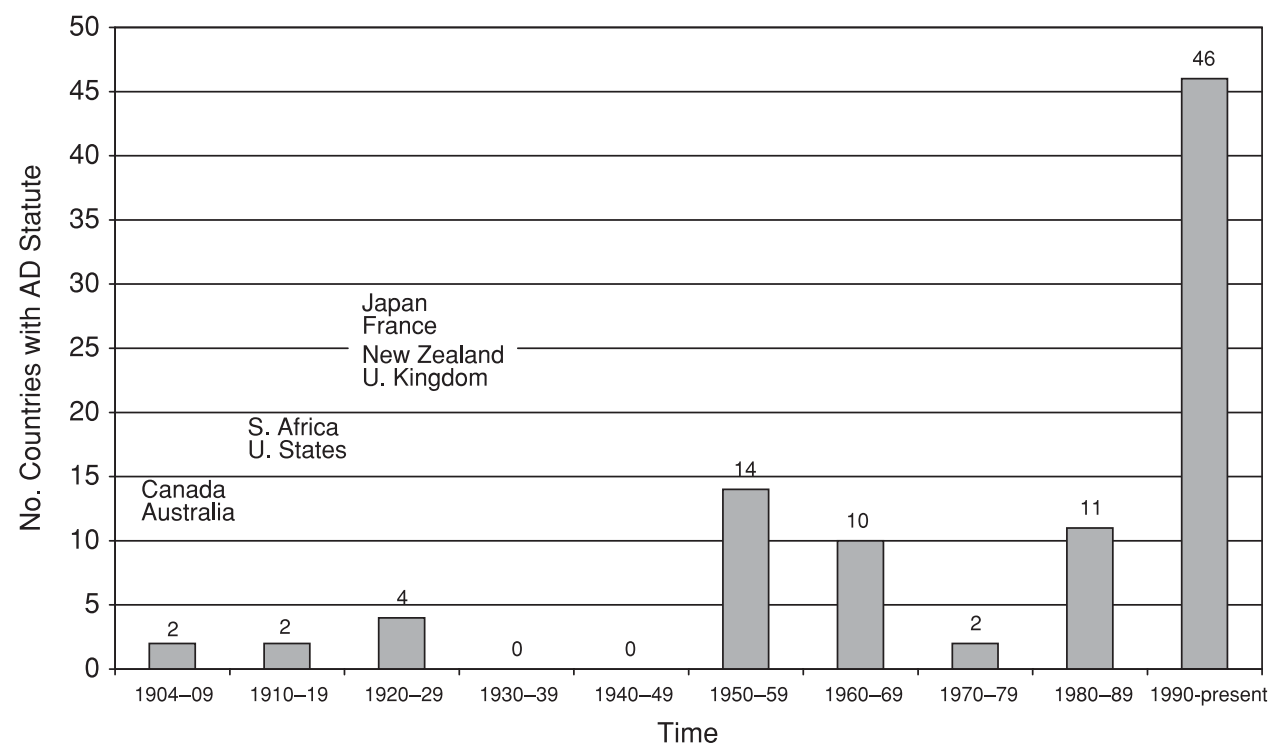

early GATT agreements. Moreover, while all GATT/WTO AD codes have been (and are) vague, the AD code in the earliest GATT agreements was particularly nebulous, little more than broad statements that dumping was a practice to be condemned. Exactly what practices constituted 'dumping', how a country should calculate dumping margins, or how a country was to ascertain injury were unaddressed. There was little thought to the precise rules and regulations that should define what a country should sanction.

As it turns out, the failure to precisely codify AD rules early on effectively signalled that $\mathrm{AD}$ was little more than a discretionary way to raise tariffs. It was inevitable, however, that GATT members formalised AD procedures. Unfortunately by the time the member countries were ready to confront tightening up $\mathrm{AD}$ rules, individual countries (most notably the EU and the United States) had institutionalised their own interpretation of the rules, making it impossible for WTO members to design AD from first principles. ${ }^{3}$

The explicit seal of approval that the GATT gave AD is a major reason why $\mathrm{AD}$ has evolved into such a significant problem for the trading community. Although the early GATT agreements did not mandate that a country enact its own AD code, it turned out that the GATT membership effectively spurred

${ }^{3}$ For example, since 1984, US AD law required mandatory cumulation of import volume. After a decade of use, the United States was eventually able to force other WTO members to adopt the cumulation provision. 
FIGURE 2

Cumulative Number of Member Countries

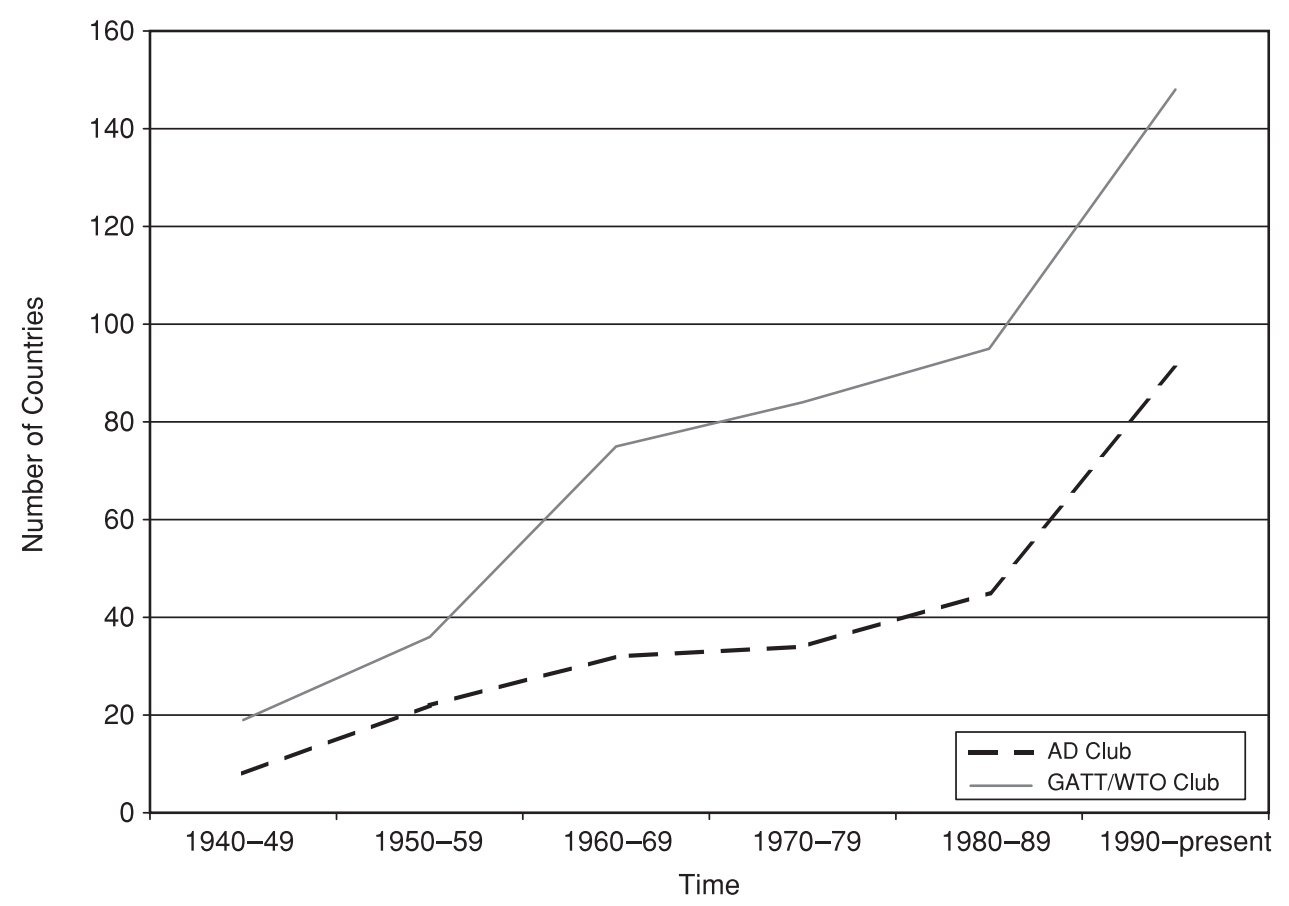

countries to do so. For instance, over the past 25 years both GATT membership and the size of the 'AD club' have almost tripled. The connection between the growing reach of the GATT and the proliferation of AD is clearly seen in Figure 2. In the figure, I plot the number of GATT/WTO members and the number of countries with an AD statute. The correlation between two series is $0.96 .{ }^{4}$

Another important point becomes clear when looking at Figure 1: the proliferation of $\mathrm{AD}$ occurred within the last $10-15$ years. While there was a steady increase in the number of $\mathrm{AD}$ users over the past 40 years, the set of users has exploded within the last $10-15$ years. Until 10-15 years ago, the AD club was quite small. More countries joined the AD club during the past decade (46) than had joined during AD's first 90 years (45).

Not only was the number of countries with an AD statute small, but the number of countries actively using their AD statute was even smaller. As hard as it is to believe, the sharp increase in new users may understate how concentrated the use of AD was until recently. As shown in Figure 3, between 1980 and 1984, only eight countries filed AD actions. Moreover, more than 97 per cent of the

\footnotetext{
${ }^{4}$ In Section 3, I will discuss reasons why GATT membership and AD use are connected.
} 
FIGURE 3

Number of Countries Using and Affected by AD

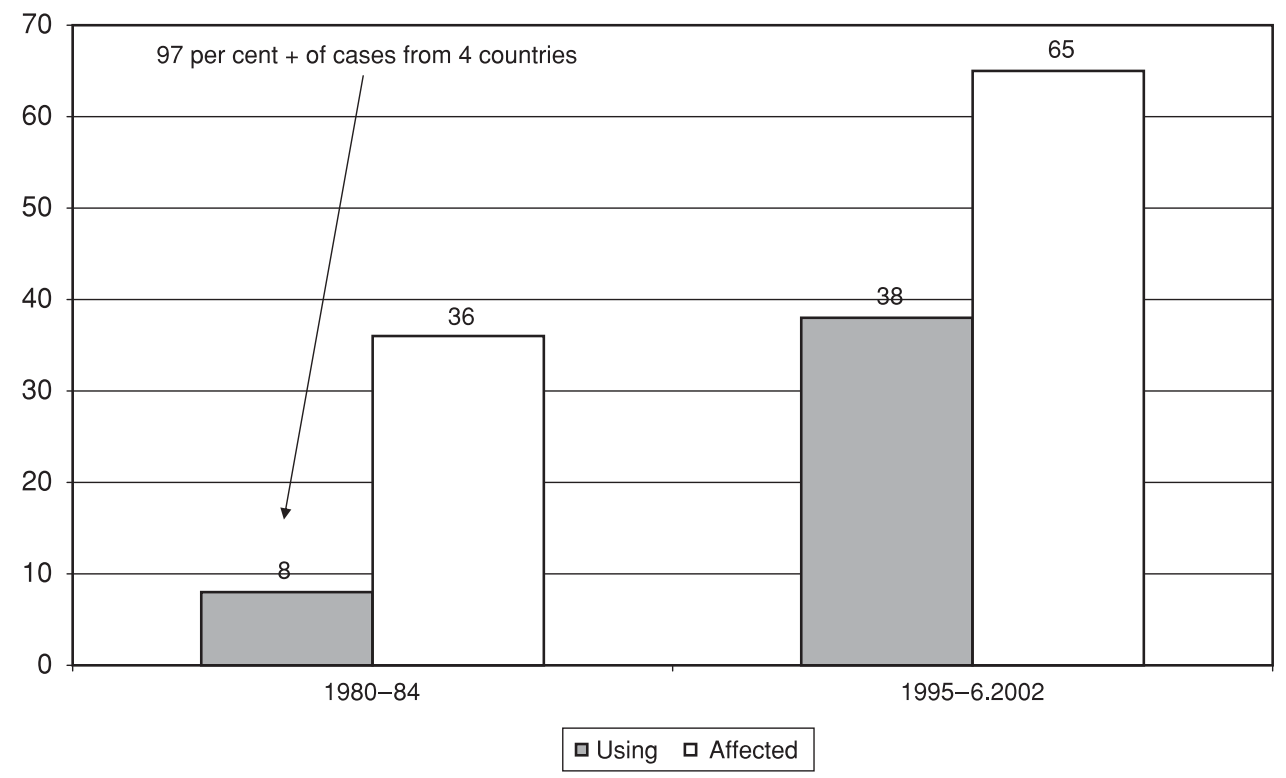

disputes were filed by just four of the users: the United States, Australia, the EU and Canada. Compare these trends with those for the most recent period. Between 1995 and mid-2002, 38 countries have filed AD disputes and the four big traditional users now account for just 40 per cent of all $\mathrm{AD}$ disputes.

The year-to-year data show that the emergence of the new users began in the mid-1980s. In Figure 4, I plot annual filing patterns for the 1980-2001 period along with the fraction of cases accounted by new users. As shown, worldwide, the number of AD actions has steadily increased over time. In the early 1980s there were fewer than 100 disputes in any given year; by the early 1990s there were 250-300 disputes per year, and by the late 1990s there were 300-350 disputes per year. The figure also shows that $\mathrm{AD}$ was once almost exclusively used by the large developed economies but is now dominated by new users. Until 1987, traditional users accounted for almost all AD activity. Every year since 1994 traditional users have accounted for less than half of all AD activity.

In Figure 5, I take the same filing data as in Figure 4 and report filings over five-year intervals and break out the filings by traditional and new users. ${ }^{5}$ Interestingly, $\mathrm{AD}$ use by the four big traditional users has been relatively constant over time, averaging about 100-125 cases per year. By contrast, the new users' filing activity increases from essentially zero in the early 1980 s to over 800 cases for

\footnotetext{
${ }^{5}$ The 2000-04 number is extrapolated using the data I have for the 2000-02 period.
} 
FIGURE 4

Worldwide AD Activity Since 1980

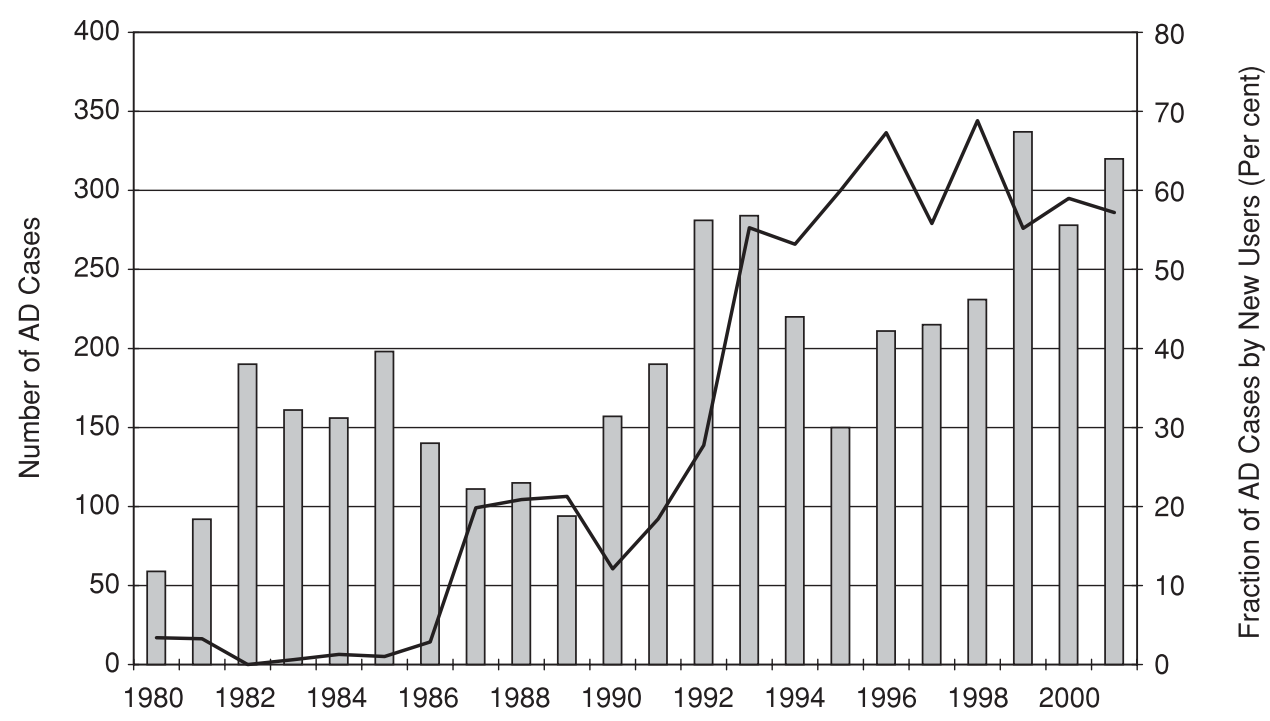

FIGURE 5

Worldwide AD Activity, Traditional and New Users

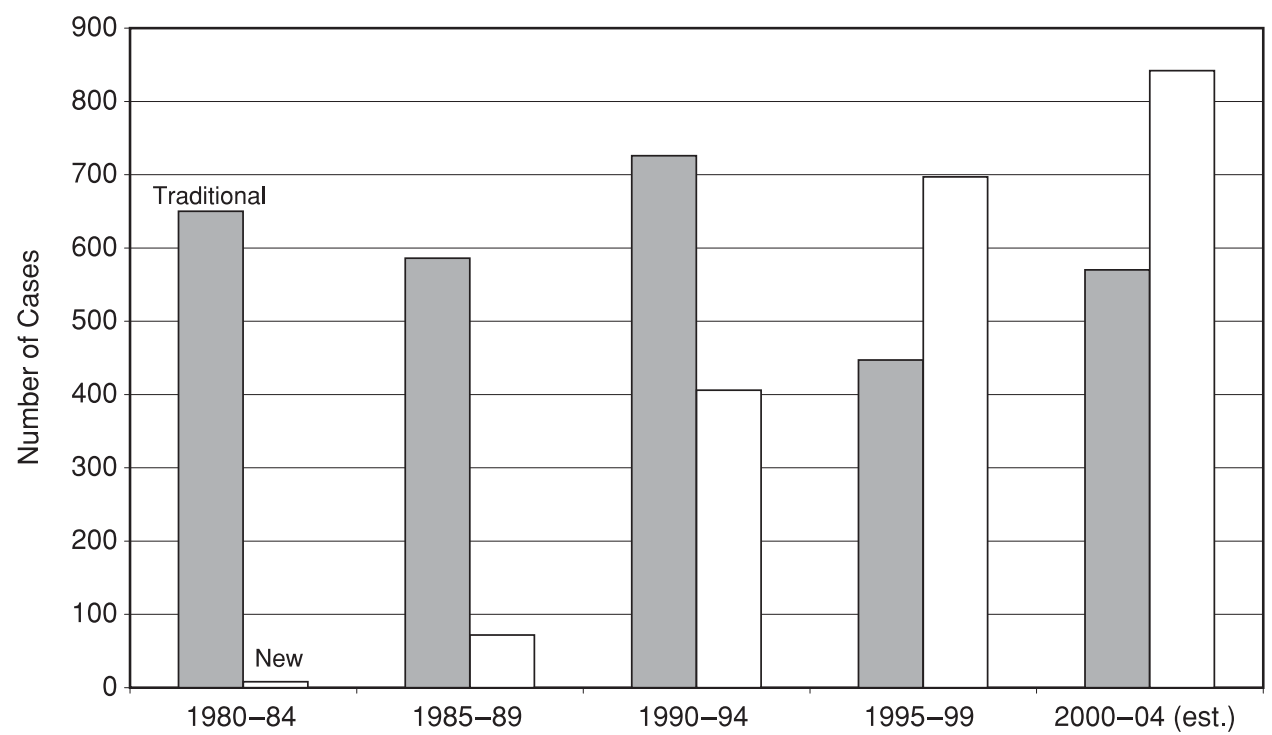

the current period. Overall, the data are quite clear: the increase in the worldwide use of $\mathrm{AD}$ actions has been driven entirely by the embrace of AD by new users. Without the proliferation of AD to dozens of new countries, AD activity would have been fairly constant over the last 25 years. 
TABLE 1

Number of AD Cases, Reporting Countries, 'Top 10 Users', 1980-2002

\begin{tabular}{lllllll}
\hline Reporting Country & $1980-2002$ & $1980-84$ & $1985-89$ & $1990-94$ & $1995-99$ & $2000-02$ \\
\hline United States & 812 & 133 & 200 & 228 & 125 & 126 \\
Australia & 760 & 228 & 164 & 237 & 90 & 41 \\
European Union & 698 & 146 & 116 & 181 & 186 & 69 \\
Canada & 424 & 143 & 106 & 80 & 46 & 49 \\
India & 275 & 0 & 0 & 15 & 120 & 140 \\
Argentina & 229 & 0 & 0 & 58 & 91 & 80 \\
Mexico & 228 & 0 & 34 & 138 & 37 & 19 \\
Brazil & 153 & 0 & 2 & 61 & 62 & 28 \\
South Africa & 148 & 0 & 0 & 14 & 110 & 24 \\
New Zealand & 72 & 0 & 8 & 30 & 24 & 10 \\
\hline
\end{tabular}

\section{b. Who's Who of $A D$}

One way to get a sense of how the world has changed is to take a look at the countries using $\mathrm{AD}$. In 1980 the list of the top $\mathrm{AD}$ users was quite short; the four traditional users accounted for all but two of worldwide AD cases. In 2002 the list of top AD users looked quite different: India (80 cases), United States (35), Thailand (21), EU (20), Australia (16), Argentina (14), Peru (13) and PR China (11). In addition, there were another dozen countries that filed AD actions in 2002. One can debate whether these filing numbers are big, but the difference over time is quite remarkable: in 2002 India filed more AD cases than the whole world did in 1980.

In Table 1, I report filing activity for the most active AD users for the 19802002 period. To streamline the table and to eliminate year-to-year fluctuations, I have aggregated the annual statistics into five-year intervals. Over the entire period, the four traditional AD users - Canada, the US, the EU and Australia top the list. As one can see by looking at the successive five-year periods, the traditional users stood alone during the early 1980s but then were joined by a growing number of new users over time. In the mid-1980s, Mexico enacted its first AD law and began intensively to use AD. Over the last 15 years, Mexico's use of AD has surpassed Canada's. As illustrated in Figure 1, in the early 1990s, Mexico was joined by a large number of other new AD-using countries. Table 1 confirms that many of these new users have embraced AD protection enthusiastically. India, Argentina, Mexico, Brazil and South Africa have all had a large number of AD filings since 1995.

Of course, one reason why we have witnessed the growth in $\mathrm{AD}$ disputes is the growth in trade. That is, as trade increases it should not be surprising to see an increase in dumping allegations. It therefore makes sense to control for the value of imports. Filing intensity not only gives an alternative measure of the long-run 
TABLE 2

Filing Intensity, Reporting Countries, ‘Top 10 Users', 1980-2002

\begin{tabular}{lrrrrrr}
\hline Reporting Country & $1980-2002$ & $1980-84$ & $1985-89$ & $1990-94$ & $1995-99$ & $2000-02$ \\
\hline United States & 155 & 185 & 224 & 225 & 51 & 91 \\
Australia & 2,173 & 3,970 & 2,678 & 3,255 & 529 & 434 \\
European Union & 131 & 179 & 144 & 176 & 93 & 62 \\
Canada & 396 & 883 & 511 & 341 & 86 & 159 \\
India & 1,861 & - & - & 1,046 & 1,413 & 3,123 \\
Argentina & 1,823 & - & - & 2,616 & 1,152 & 1,701 \\
Mexico & 674 & - & 1,165 & 1,287 & 132 & 113 \\
Brazil & 514 & - & 137 & 1,299 & 347 & 272 \\
South Africa & 1,505 & - & - & 2,136 & 1,676 & 703 \\
New Zealand & 1,205 & - & 1,295 & 2,200 & 662 & 662 \\
\hline
\end{tabular}

Note:

USA $1980=100$

growth in $\mathrm{AD}$ but also facilitates comparing $\mathrm{AD}$ activity across countries. The United States and the EU are the world's largest importers and, as a result, they might be expected to file more cases. A country like New Zealand, on the other hand, may file fewer cases but relative to how much it imports, those few cases might indicate a very active AD policy. To control for size, I compute the 'intensity' of AD use by calculating the number of cases per real dollar of imports and normalise the 'intensity' measure so that the intensity level of the world's heaviest AD user, the United States, is set to 100 in $1980 .{ }^{6}$ Countries with intensity measures greater (less) than 100 file more (fewer) AD cases per dollar of imports than the United States did in 1980.

Table 2 depicts the intensity of AD filings since 1980. A couple of interesting lessons emerge. First, the difference between new and traditional users is accentuated when we look at filing intensity. The filing intensity of the four traditional users is dwarfed by the new users. Since 1995 the filing intensity for the United States and the EU is less than 100. The filing intensities for the other top users are well in excess of 100; India and Argentina's intensities are in excess of 1,000. This means that these two countries are filing 10-20 times the frequency of the United States and the EU. If such disparity continues over time (especially if other big new users adopt an aggressive stance toward AD), it will be impossible for the United States and EU to continue to posture that $\mathrm{AD}$ is not a serious problem.

Second, one's perspective on the long-run pattern of AD usage changes depending on whether one looks at the raw numbers or the intensity rate. For example, in terms of raw numbers, US AD filings rose by 70 per cent by the early 1990s (as compared with the early 1980s) then fell in the late 1990s, and rose

\footnotetext{
${ }^{6}$ Finger, Ng and Wangchuk (2002) perform a similar calculation.
} 
sharply in the most recent period. ${ }^{7}$ In terms of filing intensity, however, US AD filings demonstrate much smaller swings.

The filing intensity for the other three traditional users has fallen more than the United States. Australia's filing intensity has fallen from about 4,000 in 1980-84 to about 400 in 2000-02. The EU's filing intensity has fallen from 179 in 198084 to 62 in 2000-02. Canada's filing intensity has fallen from 883 in 1980-84 to 159 in 2000-02. Overall, the pattern for all four traditional AD users is broadly similar: a sizeable decrease in filing intensity over the past 25 years.

The trend in the filing intensity of the other top users (who are all considered 'new' users) is much more mixed. The filing intensity for many new users has increased over the past 15 years. For India, for instance, the filing intensity has almost tripled over the last decade. For other new users, like Brazil and Mexico, the filing intensity has fallen.

It is difficult to project what the new users' filing intensity will look like over the next decade. One possibility is that filing intensity decreases over time. This trend is consistent with the traditional users' trend and also the older 'new' users like Mexico, Brazil and New Zealand. A declining trend might materialise if high filing intensity reflects the desire to protect a small number of politically important industries, and, once these industries have received protection, the amount of $\mathrm{AD}$ activity falls. On the other hand, high filing intensity might reflect that the new users simply have a loose interpretation of the WTO AD rules. Nevertheless, even if the new users' intensity decreases, their relatively small import volumes make it likely that their filing intensity will exceed that of the traditional users.

\section{c. AD - From Rich to Poor}

Another way to capture the proliferation of AD is to look at how its use has spread from rich to poor countries. To calculate this, I used the World Bank classification system and grouped each country into one of five groups: (i) High Income OECD, (ii) High Income Non-OECD, (iii) Middle Income Upper, (iv) Middle Income Lower and (v) Low Income. Using these groups, I tallied total filings and filing intensity and present the results in Table 3. Once again I have aggregated the annual statistics into five-year intervals.

The table tells the same basic story but the trends are even starker than those presented in Tables 1 and 2. Over the entire sample period, the high income OECD countries dominate the filings, accounting for two-thirds of all AD disputes. Their share, however, has declined appreciably over time. Over time, the share of AD cases accounted for by high income OECD countries has declined from 100 per cent (1980-84) to 94 per cent (1985-89) to 67 per cent (1990-94) to 41 per cent (1995-99).

\footnotetext{
${ }^{7}$ Remember the most recent period is only three years.
} 
TABLE 3

Number (Intensity) of AD Cases, Reporting Countries

\begin{tabular}{lcccccc}
\hline $\begin{array}{l}\text { Reporting Country's } \\
\text { Income Level }\end{array}$ & $1980-2002$ & $1980-84$ & $1985-89$ & $1990-94$ & $1995-99$ & $2000-02$ \\
\hline High Income OECD & 2,806 & 658 & 616 & 764 & 471 & 297 \\
& $(230)$ & $(361)$ & $(303)$ & $(298)$ & $(91)$ & $(95)$ \\
High Income Non-OECD & 32 & 0 & 0 & 5 & 16 & 11 \\
& $(147)$ & - & - & $(106)$ & $(262)$ & $(73)$ \\
Middle Income Upper & 926 & 0 & 42 & 294 & 409 & 181 \\
& $(497)$ & - & $(436)$ & $(954)$ & $(316)$ & $(281)$ \\
Middle Income Lower & 217 & 0 & 0 & 54 & 97 & 66 \\
& $(459)$ & - & - & $(916)$ & $(254)$ & $(207)$ \\
Low Income & 320 & 0 & 0 & 15 & 154 & 151 \\
& $(1,062)$ & - & - & $(1,046)$ & $(795)$ & $(1,346)$ \\
\hline
\end{tabular}

Note:

Intensity defined where USA $1980=100$.

The table makes it clear that the 'new user' story is more nuanced than my above discussion suggests. The proliferation of AD behind the traditional users' falling share does not simply mean that AD is being used more by 'rich countries'; rather, AD use is moving down the income distribution. It is not only rich or middle-income countries that file AD cases: there has been a systematic spread of AD from rich to poor countries. Beginning in the mid-1980s, upper-tier middle income countries like South Korea, Mexico and Brazil began to use AD. Then in the early 1990s, lower-tier middle income countries like Turkey, Peru, Colombia and Egypt joined the AD club. Finally, in the mid-1990s, even low income countries such as India, Indonesia and Nicaragua began aggressively to seek AD protection. Today, the countries most intensively using $\mathrm{AD}$ are poor countries like India and PR China.

The new reality depicted in Table 3 must be troubling for AD's two strongest supporters: the United States and the EU. They would like to retain AD so that they can protect their politically important industries. Yet, preserving this option means that many politically important export-oriented industries now face $\mathrm{AD}$ protection in many important export markets.

\section{REASONS FOR THE WIDESPREAD ADOPTION OF AD}

The previous section presented strong evidence that $\mathrm{AD}$ has proliferated to all parts of the world. The trends beg the question: why is AD so widely used? For some the answer is obvious. There are so many AD disputes because there is so much unfair trade. At some level, this answer is correct, yet it is also entirely unsatisfactory. A better answer would also address a series of related questions. Why is there so much unfair trading? Is it because we have defined unfair oddly? 
Why have we seen an increase in unfair trading? And, why is trade causing injury now and not in earlier periods? Below I sketch some of the underlying reasons why there is so much $\mathrm{AD}$ activity.

\section{a. Reason No. 1: The Language of 'Unfairness'}

The language of $\mathrm{AD}$ is unbeatable, making the statute almost impervious to criticism. Since all but a handful of experts actually understand the actual legal provisions of $\mathrm{AD}$, the debate surrounding $\mathrm{AD}$ often hinges on a deceptively simple phrase, 'unfair trade'. The fact that what lawyers define as 'unfair' makes no economic sense is lost on many commentators. AD supporters understand this and do their best to keep the discussion on broad terms. Their position - that dumping violates principles of fair trade and as such must be condemned sounds reasonable if not patriotic. To the man on the street, the broad description makes $\mathrm{AD}$ sound fine and vaguely reminiscent of anti-trust law. The rhetoric of 'free but fair' trade is irresistible. After all, who is in favour of unfair trade?

As a consequence virtually any provision in the AD laws is immune to criticism. In the political arena, to say you are against $\mathrm{AD}$ (or even some provision of $\mathrm{AD}$ ) is quickly spun as meaning you are in favour of unfair trade. Part of the problem is that many of the provisions are arcane and very difficult to understand. The 'facts available' provision is one of the more easily articulated of the 'arcane' rules. 'Facts available' defines when government agencies can use other sources of information to determine the foreign firm's dumping margin. Obviously, determining that a foreign firm is unfairly trading is considerably easier when you ignore the foreign firm's pricing and cost information (or augment the foreign firm's information with outside data).

The justification for facts available is that it encourages the foreign respondents to participate in the process so that the government can get the most accurate assessment of the extent of their unfair trading. If the foreign firm refuses to provide information, how else can the investigating agency determine margins? As a practical matter, however, facts available often discourages foreign participation since the rule gives the investigating government extremely broad latitude to reject their submission. In other words, facts available does the opposite of its desired effect. A foreign firm can literally spend millions of dollars preparing its submission and have the investigating agency reject its data as unsatisfactory. If foreigners cannot meet the government's required, yet arbitrary, reporting requirements (which have nothing to do with standard accounting practices), then the government can ignore the foreign information. ${ }^{8}$

As Lindsey (1999) discusses, facts available often means the margins are based on some other country's prices and costs rather than the country that is

\footnotetext{
${ }^{8}$ Murray (1991) contains an excellent discussion of the methods used to calculate dumping margins.
} 
actually being accused of dumping. In effect, a country can convict Malaysia of dumping based on information it has collected for Spain! Yet, to criticise this provision will mean that you are in favour of unfair trade.

\section{b. Reason No. 2: The Lack of Economic Foundation}

Despite the fact that AD proponents often make reference to 'sanctuary markets', 'foreign cartels' and 'establishing level playing fields', there is no sense in which $\mathrm{AD}$ protects the competitive marketplace. ${ }^{9}$ While it is true that $\mathrm{AD}$ was originally conceived as an extension of domestic anti-trust (competition) law and was designed to protect competition, this has not been the case for more than 70 years. Today, $\mathrm{AD}$ is designed to protect domestic competitors from foreign competition.

A creative AD authority can impose WTO-consistent AD duties pretty much under any possible scenario. One of the most basic lessons to understand is that rather than being an economically meaningful calculation, $\mathrm{AD}$ is an extremely complicated, highly discretionary accounting exercise. AD duties can be imposed when: (1) the foreign firm's export price is higher than its own home price; (2) the foreign firm's export price (to the market in question) is higher than its price in other export markets; and (3) the foreign firm's export price is higher than the price charged by the complaining domestic firm. A foreign firm can be convicted of dumping even though it is the highest-price firm in the market. To the extent that price matters, the question is often why the foreign firm is not charging an even higher price. And, it is not the case that profitability rather than price matters. $\mathrm{AD}$ duties can be imposed when the foreign firm is making large profits on its export sales.

The reason behind all of these seemingly paradoxical outcomes is that AD rules are not grounded in microeconomics. Under GATT/WTO rules, the investigative authority need not try to determine whether the foreign firm has predatorily priced, priced below marginal cost, or intended to injure the domestic industry. Rather, the authority must determine: (1) whether the foreign firm has priced lower in its export market than at home, or (2) whether the foreign firm has priced below 'fully loaded' cost. The cost-based method is particularly confusing because it sounds like an anti-trust-type 'pricing below marginal cost' calculation. However, under AD rules, the cost method is closer to something like pricing below average costs (where additions for 'profit' and overhead are added to the average cost calculation). Because of the ad hoc add-ons allowed on AD rules, a foreign firm making large profits on its export sales can nonetheless be deemed to have sold below costs.

\footnotetext{
${ }^{9}$ Mastel (1998) argues in support of AD. He devotes a large section of his justification that it is needed to protect US firms and consumers from foreign predatory practices. Yet there is nothing in the law that requires any evidence of such practices.
} 
At least as damning is that neither the price-based nor cost-based method truly is designed to 'level the playing field'. Under current rules, the foreign firm must price significantly higher on its export sales than its home market sales in order to avoid duties. Why? Because GATT/WTO AD rules allow the AD authority to make a myriad of complicated price and cost adjustments. In theory, these adjustments are supposed to allow an 'apples to apples' comparison of foreign and domestic prices. Yet, the WTO rules are sufficiently broad that a politically motivated AD authority can use these adjustments to create margins. AD authorities have large latitude to construct price and cost comparisons so as to achieve the policy goal, namely, protecting the domestic industry. If the foreign firm's export price seems high, ad hoc adjustments can be made to lower it; if the foreign price is higher than the complaining domestic firm's, the argument is made that dumped imports suppressed the domestic firm's price (i.e., the foreign firm's price is high, but not sufficiently high enough to have no impact on the competing domestic firm).

\section{c. Reason No. 3: Discretion}

The discretion involved in an $\mathrm{AD}$ case is subtle, intricate and considerable. While the theoretical justification for $\mathrm{AD}$ is weak, it is the practical implementation that makes $\mathrm{AD}$ protection particularly egregious. For instance, exactly how one calculates dumping margins is anything but a simple accounting exercise. In many cases, comparable products are not sold in sufficient quantities at home and abroad. If they are not, the investigating government must use some discretion to determine the adjustments needed in order to come up with comparable products. And even if the products are comparable, AD authorities still often find grounds to adjust prices. If comparable products are sold at home and abroad, a myriad number of Byzantine adjustments and offsets are allowed. At the end of the day, government accountants can come up with just about any margin they want. ${ }^{10}$

Sound hard to believe? Over the 1980-2000 period, the United States arguably the country with the most transparent methodology and most well established precedent and procedures for calculating margins - has imposed AD duties in more than 95 per cent of its investigations. It is not uncommon for the US Department of Commerce to go two or three years without a single negative dumping determination. Moreover, the margins are not trivial. Blonigen (2003) reports that in recent years the average US dumping margin is about 65 per cent.

Even more unsettling is that the US approach appears to be mild compared to some of the new users. While a systematic accounting has not been done,

${ }^{10}$ Blustein (2003, p. F01) discusses the open secret that the US Department of Commerce 'margin shops', which means they perform their calculations under a variety of alternative assumptions in order to obtain the highest possible margin. 
preliminary work on several of the largest new AD users suggests that the United States may be the best of a bad lot. For instance, I reviewed margin calculations for the biggest of the new AD users, India, and found that the average dumping margin is about 80 per cent.

Think about what the government agencies are asserting when they report such margins. A 65 per cent dumping margin means that the foreign firm is either charging 65 per cent less on its export sales than on its home market sales or that it is selling 65 per cent below its cost of production. Is this plausible? Whether it is or not, the AD law means that the foreign firm's exports will be subject to a 65 per cent tariff.

\section{d. Reason No. 4: Consistent But No Concessions}

$\mathrm{AD}$ protection with all of its discretion and vagueness is encoded in the GATT and WTO agreements. AD is WTO-sanctioned protectionism. And, unlike the safeguard statute, WTO AD rules do not require the AD duty-imposing country to offer compensating tariff reductions to the affected country. Nor can the affected country retaliate. ${ }^{11}$ This means that countries can levy AD duties with no fear of retaliation and little fear of WTO appeal. Even if an affected country appeals the AD duty and even if the WTO Dispute Settlement Body rules in its favour, the country imposing the AD duty need not remove the duty but rather can just tweak its calculations, re-write its justifications for imposing the duty, and put the burden back on the complaining party to seek further redress. ${ }^{12}$

All things considered, no other trade instrument offers as much protection with so little risk as AD: large duties are easily imposed; affected countries have little ability to meaningfully appeal and have no ability to directly retaliate.

\section{e. Reason No. 5: The Failure and Success of GATT/WTO Negotiations}

As shown in Figure 2, since the formation of the GATT, the steady increase in the number of countries having an AD statute has largely reflected the steady increase in GATT/WTO membership. Does AD proliferation have anything to do with the GATT/WTO? I think the answer is clearly 'yes', and the reasons are rooted in both the failure and the success of the negotiations.

First, the failure. As discussed earlier, for the first 75 years of its existence, $\mathrm{AD}$ was a trade instrument regularly implemented by only a handful of countries.

\footnotetext{
${ }^{11}$ According to the Uruguay Round agreement, under normal circumstances, safeguard actions are only subject to retaliation after they have been in place for three years.

12 The softwood lumber case is a well-known example of this phenomenon. Despite having the WTO Appellate Body rule against it on several occasions, the United States continues to impose duties on Canadian softwood lumber.
} 
In addition, the $\mathrm{AD}$-using countries tended to target imports from other AD-using countries, effectively creating an AD club (Finger, 1991; and Prusa and Skeath, 2002). As a result, AD was a non-issue for many countries. It was easy for non$\mathrm{AD}$ club members to look the other way and let club members do what they wanted with AD. The GATT/WTO failed by not developing economically meaningful rules for implementing AD. Instead, it was expedient to allow interested parties (i.e., the EU and United States) to design loopholes whereby prohibitive tariffs could be levied. These loopholes were acceptable because they were exploited in fairly small numbers by a handful of countries.

Second, the success. Part of the answer why AD has proliferated lies with the success of the GATT in lowering tariffs. As countries join the GATT/WTO, tariffs are often lowered. This can lead long protected domestic industries to finally confront international competition. Not wanting to do so, these industries quickly realised that they can use $\mathrm{AD}$ to restore order to the domestic market. The new users understood that long, hard-fought tariff concessions could be quickly 'undone' by imaginative use of the AD statute.

\section{CONCLUDING COMMENTS}

Twenty years ago it might have been reasonable to say that AD mattered only for four or five countries. The same cannot be said today. AD affects countries all across the globe and all across the income distribution and development spectrum. As a result, the political consensus for AD reform is changing. During the Uruguay Round, for instance, one could pretty accurately predict a country's position toward AD by simply looking at per capita GDP. Rich countries advocated for and poor countries lobbied against $\mathrm{AD}$ (to the extent that they cared about AD). Today, the picture is far messier. Traditional AD proponents - the United States and the EU - are as likely to find supporters as detractors for their $\mathrm{AD}$ proposals among the developing countries.

A concern is that the widespread embrace of $\mathrm{AD}$ protection makes the prospect for $\mathrm{AD}$ reform increasingly unlikely. In the near term, strong opposition by the United States and the EU makes reform a highly unlikely outcome. In the longer run, the rising use of $\mathrm{AD}$ against the United States and the EU could conceivably weaken their support for AD. Yet, the same trends that might finally cause the United States and the EU to realise that AD is a failed policy will likely make reform impossible. The new users who have adopted and aggressively embraced AD may decide that it is a policy that they cannot live without. As a result, the Doha Round may be the last chance to significantly reform AD rules. Thereafter, by the next WTO round, there may only be a handful of countries who have not succumbed to AD's unique combination of GATT/WTO consistency, arbitrary (often prohibitive) duty levels and discretionary provision. 
Even if $\mathrm{AD}$ rules are not formally reformed, there seem to be two possible scenarios: an 'AD cold war' or an 'AD epidemic'. Blonigen and Bown (2003) provide empirical support for the cold war theory. They show that holding other factors constant, the United States tends to file AD actions against countries that do not have an AD statute. One interpretation of their results is that a country's ability to use $\mathrm{AD}$ discourages other countries from using $\mathrm{AD}$ against it. The threat of retaliation deters others. If this is correct, it is possible that eventually all countries will have an AD statute but we will see very little AD activity - each country will be afraid to use AD because doing so will mean their exports will be hit with $\mathrm{AD}$ duties.

On the other hand, my view is that an 'AD epidemic' scenario is at least as likely. The reason is that $\mathrm{AD}$ cases are almost always initiated by industries, not by governments. For the cold war theory to emerge, there must be some cost imposed on industries that seek AD protection. Given that most industries that use $\mathrm{AD}$ do not have much export exposure, it is not obvious why they should fear other countries using AD. The US steel industry, for example, exports very little of its output. Why should the possibility that India will impose AD duties on, say, wheat, discourage the US steel industry from seeking AD protection on Indian steel?

If the cold war scenario materialised, then there will be no pressing reason to think that the WTO will ever address AD. On the other hand, if the epidemic scenario materialises, $\mathrm{AD}$ rules will have to be addressed. My view is that $\mathrm{AD}$ can be addressed only when powerful US and EU exporters - who currently are largely unaware of the perverseness of AD rules - feel its wrath. The day that Microsoft, Intel and Hollywood media companies find their products subject to 50 per cent tariffs will be the day when Washington decides that AD rules are too easily manipulated. The day that Vivendi, BASF, Braun, SAP and Siemens find their products subject to 50 per cent tariffs will be the day that Brussels decides that $\mathrm{AD}$ should be reined in. The trouble is that by that time so many other countries will have embraced $\mathrm{AD}$ that reform will be difficult to achieve.

\section{REFERENCES}

Anderson, J. E. (1992), 'Domino Dumping I: Competitive Exporters’, American Economic Review, 82, 1, 65-83.

Blonigen, B. A. (2003), 'Evolving Discretionary Practices of US Antidumping Activity', NBER Working Paper No. 9625.

Blonigen, B. A. and C. P. Bown (2003), 'Antidumping and Retaliation Threats', Journal of International Economics, 60, 2, 249-73.

Blustein, P. (2003), 'When the US Thinks Goods Were “Dumped”, He Steps Up', Washington Post (13 July), F01.

Finger, J. M. (ed.) (1991), Antidumping: How It Works and Who Gets Hurt (Ann Arbor, MI: University of Michigan Press). 
Finger, J. M., F. Ng and S. Wangchuk (2002), 'Antidumping as Safeguard Policy', in R. M. Stern (ed.), Issues and Options for US-Japan Trade Policies (Ann Arbor, MI: University of Michigan Press).

Lindsey, B. (1999), 'The US Antidumping Law: Rhetoric versus Reality', CATO Institute Centre for Trade Policy Studies Working Paper No. 7.

Mastel, G. (1998), Antidumping Laws and the US Economy (Armonk, NY: M. E. Sharpe).

Miranda, J., R. A. Torres and M. Ruiz (1998), 'The International Use of Antidumping: 1987-1997', Journal of World Trade, 32, 5, 5-71.

Murray, T. (1991), 'The Administration of the Antidumping Duty Law by the Department of Commerce', in R. Boltuck and R. E. Litan (eds.), Down in the Dumps (Washington, DC: Brookings Institution).

Prusa, T. J. (1992), 'Why Are So Many Antidumping Petitions Withdrawn?', Journal of International Economics, 33, 1-2, 1-20.

Prusa, T. J. (2000), 'On the Spread and Impact of Antidumping', Canadian Journal of Economics, 34, 3, 591-611.

Prusa, T. J. and S. Skeath (2002), 'The Economic and Strategic Motives for Antidumping Filings', Weltwirtschaftliches Archiv, 138, 3, 389-413.

Shin, H. J. (1998), 'Possible Instances of Predatory Pricing in Recent US Antidumping Cases', in R. Z. Lawrence (ed.), Brookings Trade Forum 1998 (Washington, DC: Brookings Institution), 81-97.

Zanardi, M. (2004), 'Antidumping: What are the Numbers to Discuss at Doha?', The World Economy, 27, 3, 403-33. 